\title{
Promoting Investment through State-Owned Enterprises and Endowment Companies in Ethiopia's Pastoral Areas: Legal and Policy Analysis
}

\author{
Seid Demeke Mekonnen \\ Candidate in Law, City University of Hong Kong, Hong Kong, China \\ Email: smekonnen2-c@my.cityu.edu.hk
}

How to cite this paper: Mekonnen, S. D. (2019). Promoting Investment through State-Owned Enterprises and Endowment Companies in Ethiopia's Pastoral Areas: Legal and Policy Analysis. Beijing Law Review, 10, 246-259.

https://doi.org/10.4236/blr.2019.101015

Received: February 16, 2019

Accepted: March 22, 2019

Published: March 25, 2019

Copyright $\odot 2019$ by author(s) and Scientific Research Publishing Inc. This work is licensed under the Creative Commons Attribution International License (CC BY 4.0).

http://creativecommons.org/licenses/by/4.0/

Open Access

\begin{abstract}
The current investment trends in Ethiopia indicate that the private sector is not willing to invest in remote areas. This is due to the fact that the central objective of the private companies is profit maximization in any business activity. Hence, anticipating merely the private sector's investments doesn't work for Ethiopia's pastoral areas. State-owned enterprises (SOEs) and endowment companies should be taken as alternative means to promote investments in those remote pastoral areas. Obviously, the SOEs can be established by the federal and regional governments of Ethiopia, whereas the endowment companies can be established by charitable endowments which need to be non-political party-affiliated. The constitutional basis for establishing those entities may be challenged due to the existence of some concerns over the operation of the existing ones. The writer of this article is of the opinion that there are adequate legal and policy justifications as well as practical necessities for promoting SOEs and endowment companies. The need for promoting investment through those business entities is uncontestable as the private sector is reluctant to invest in the remote pastoral areas. The main objective of this article is to investigate the policy and legal justifications for promoting investment through SOEs and endowment companies in Ethiopia's pastoral areas. Moreover, the article suggests the compatible political economy model to strengthen a government-led investment, for the purpose of this article, in pastoral areas.
\end{abstract}

\section{Keywords}

Endowment Companies, FDRE Constitution, Investment, Pastoral, State-Owned Enterprises 


\section{Introduction}

The past legislative decisions of Ethiopia indicate the socio-economic matters of the pastoral community were not sufficiently addressed. This situation has resulted in socio-economic inequality between the pastoral and non-pastoral areas of the country. The problem is also continued, to some extent, in the present regime, the Federal Democratic Republic of Ethiopia (FDRE). The government has not practically created economic development that uplifts the pastoral community from poverty. That is why the recent drought and famine have been affecting the pastoral areas more than any other parts of the country.

Some of the government financial regulations have created an obstacle to the creation of a pastoral community having a middle-income economy. It is apparent that the role of banks is very crucial in creating a middle-income economy. However, the government has abolished the financial regulation that allows the formation of interest-free banks which could benefit the vast majority of the pastoral community who accounts about $15 \%$ of the country's population.

Nonetheless, it does not mean that there is no positive effort at all. In the Ethiopian growth and transformation plan I (GTP I), the issue of pastoral development is somewhat addressed and the plan is executed from 2010/11-1014/15. As a second phase, this plan is being implemented and will end after two years. Moreover, micro-financial institutions are allowed to provide interest-free services in pastoral areas. Overall, promoting state-owned enterprises and endowment companies in the pastoral areas can be the best option to compensate for the past economic marginalization and the gaps created due to the lack of interest-free banks.

The methodology employed when conducting this research was a qualitative approach. The study has used both primary and secondary sources so as to generate quality data. As primary sources, the FDRE Constitution and the proclamations of investment, microfinance institutions, state enterprises, and charitable and civil society organizations are consulted. As secondary sources, pertinent policies, strategies, and different literature are reviewed. Finally, the findings obtained from the qualitative data sources are integrated to reach an equivalent conclusion.

\section{Pastoral Community in Ethiopia: An Overview}

The pastoral communities represent about $15 \%$ of Ethiopia's population and approximately $40 \%$ of the land area of Ethiopia is considered to be under pastoral production (Sara \& Mike, 2008). The total direct economic contribution of pastoralist to the Ethiopian economy (through the production of milk, meat, skin, hides, etc.) is very significant which accounts for about $6 \%$ of the agricultural GDP per annum (Sara \& Mike, 2008). Despite their economic contribution, there has been a fundamental misunderstanding of the pastoral production system in Ethiopia (Hogg, 1997). There is a general perception among policy and lawmakers that pastoral lands are underused and therefore should be brought 
under the plow or put to other uses such as ecotourism. Such misperceptions have subjected pastoral communities to political and economic marginalization (Eyasu Elias \& Feyera Abdi, 2010).

Resource alienation and curtailment of mobility have made pastoral households vulnerable to frequent droughts, food insecurity, and famine (Gadamu 1994). Policy engagement by pastoralists on key environmental issues has been weak partly due to a lack of field-based empirical evidence on pastoral land alienation and destitution (Zelalem Ylma et al., 2009).

Mobile pastoral communities have been coping with changing environmental conditions for centuries, and as a result, they have a long established capacity for adaptation. (Gadamu, 1994) However, changes in their environment in recent years-including the increasing frequency of drought, land fragmentation, and natural resource degradation-have undermined their adaptive strategies, which are now increasing their vulnerability (Holly Welcome Radice, et al., 2011). Trends point to a pattern of climatic hazards that are more frequently turning to disasters. One option for pastoralist and agro-pastoralists is to build on their adaptive capacity and resiliency using a response that is closely based on their skills in managing natural resources (Holly Welcome Radice, et al., 2011).

Pastoralists' livelihood is mainly intertwined with livestock resources. Improving pastoralists' livelihood is inseparable from the development of resources (FDRE, 2010). Livestock production is not only important to pastoralists, but it is also vital to the economy of many crop farmers as well. As with crop production, the performance of this sub-sector has been greatly hampered by recurrent drought and other supply-side problems (Assefa Admassie \& Degnet Abebaw, 2014). There is a need for policies and enabling legislation decisions to support the participation of pastoralists in markets to strengthen their livelihoods alongside targeted measures to support those who are being left behind (Future Agricultures, 2011).

\section{Policy Framework Pertinent to Pastoral Matters}

The history of development-oriented policies and legal frameworks of Ethiopia show that the socio-economic matters of the pastoral community are not sufficiently addressed. Nonetheless, this historical defect is being corrected by the current government. Since 2001, the socio-economic interests of the pastoral community have been incorporated in the government policies and legal frameworks. This can be evidenced by the past development plans of the country: Sustainable Development and Poverty Reduction Program (MoFED $\left.{ }^{1}, 2002\right)$, and Accelerated and Sustainable Development to End Poverty (MoFED, 2006).

Moreover, in GTP I the interest of the pastoral community is somewhat addressed. It has made reference to pastoralist aiming at strengthening agricultural development activities in pastoral areas to raise the standard of living and improve nomadic livelihoods step by step (FDRE2, 2010). However, the productiv-

${ }^{1}$ Ministry of Finance and Economic Development (MoFED).

${ }^{2}$ Federal Democratic Republic of Ethiopia (FDRE). 
ity of the livestock sub-sector, which is the principal means of livelihood for the pastoralists, has been at its lowest level during the implementation of this plan (FDRE, 2015). Under GTP II, it is planned to improve the livestock sub-sector with the objective of adequately exploiting its potential for growth, export earnings, and job creation. The strategies designed to realize these objectives are improving animal health, animal feed and animal breed with targets to increase the productivity of meat, milk, honey, and egg. However, the writer of this article doubts the effectiveness of GTP II in transforming the livestock sector to the required level.

As explained above, under GTP I, pastoral matters have been somewhat addressed at the textual level (FDRE, 2010). Nevertheless, under GTP II, there is a gap in the document, that is, the required attention is not given to the pastoral development matters. Cross-cutting issues like building climate resilient green economy are made as the policy and strategic pillar of the plan (FDRE, 2015). But, the agenda of pastoralists, who constitute $15 \%$ of the population, is not treated as one pillar. Of course, the pastoral development matters may be addressed in specific documents that could be formulated to implement the GTP. Nonetheless, policy attention implies budget priority-the policy implementing institutions of the government pay more attention to the strategic pillars. Here, the suggestion is the pastoral regional states need to fill such a gap when implementation the GTP. The regions should formulate specific policies that priorities poverty reduction in the pastoral context-focusing on alternative income generation schemes like establishing state-owned enterprises and endowment companies.

Furthermore, micro-finance institutions, that are compatible with the special needs of the pastoral areas, should be expanded. Accessible and flexible financial services are among the basic ingredients for rapid economic development of a society at any level. Recognizing this issue, financial system-advancement has been taken as one policy direction and strategy in the overall fight against poverty in Ethiopia. The role of micro-financial institutions is very important and even irreplaceable.

Following the promulgation of proclamation number 40/1996, after one year from the coming in to force of the FDRE Constitution, a number of micro-finance institutions were established and have been operating in the rural areas of Ethiopia. But, these institutions are not accessible to the pastoral community in general (Pastoral Development in Ethiopia, 2004).

Recently, some NGOs and government-run micro-finance institutions are trying to provide non-conventional financial services, particularly interest-free credits in pastoral regions by special permission from the National Bank of Ethiopia (Pastoral Development in Ethiopia, 2004). This is a good approach. However, when we look at the experience of Somali region, as an example, the rural pastoral communities are not utilizing the interest-free credits basically due to lack of awareness as to the introduction of this new system. Hence, regional governments need to work for the accessibility of the micro-finance institutions 
and conduct advocacy as their services are sharia-friendly.

To let GTP II and pastoral-oriented poverty reduction policies work in pastoral areas, it is decisive to consider micro-finance institutions as one major alternative income generation means to the pastoralists. Accordingly, priority should be given to rural micro-finance for food security. This may include credit and savings needed for agricultural production and off-farm enterprises. It may also include other demands for financial services such as financing food consumption and health care as well as providing households' with more effective savings, credit and insurance services for smoothing consumption, holding precautionary savings and diversifying the asset portfolio (Zeller, M., et al., 1997).

Overall, the following alternative income-oriented way outs can be taken as crucial inputs to improve the livelihood of the pastoral community.

- With a view to creating alternative income generation to the pastoral communities, federal and regional governments should expand and access micro-finance institutions.

- The federal and regional governments should provide intensive training and support for those who engage in alternative income generation activities. The pertinent bodies should promote entrepreneurism through formulating workable legal, policy and institutional frameworks.

- The governmental and non-governmental agencies should work for the integration of marketing into the livestock sector. Accordingly, to mitigate risks and to ensure the profitability of the livestock market, the pertinent bodies should create a conducive environment to the pastoralists and private investors. This includes formulating workable policies, legal and institutional frameworks, providing an incentive like tax exemption to the private investors, and creating regional and international market channels.

\section{Establishing State-Owned Enterprises and Endowment Companies: The Legal Basis}

Livestock number and its productivity are decreasing from time to time due to the recurrent drought, shrinkages of grazing lands, and the overall environmental degradation. As a result, large numbers of pastoralists are becoming food insecure. The livestock productions need to be supplemented with non-livestock income generating means that enable the poor to earn additional cash incomes (Nur Abdi Mohammed, 2006). Pastoralists are increasingly affected by poverty, especially due to the lack of alternative income generation options. Hence, it is very helpful if the government itself and charitable endowments fully engage in some relevant investment activities through SOEs and endowment companies respectively to create job opportunities to the pastoralists. Appraising the legal and policy basis and the practical necessity of establishing such business organizations is important, as it will be elucidated herein under.

\subsection{Investment through State-Owned Enterprises}

According to the Ethiopian investment laws, an investor who invests in the rela- 
tively under-developed regions of Gambella, Benishangul Gumuz, South Omo, Afar, or Somali Region will be eligible for income tax deduction of $30 \%$ for three consecutive years (Ethiopian Investment Commission, 2012). However, most of the foreign investments inflow into the capital city, Addis Ababa, and its surroundings because of the availability of the basic infrastructures like roads, power/electricity, and banking and communication systems. The foreign investors have rarely interested in the pastoral areas due to a lack of infrastructure coupled with security issues.

For example, in Somali regional state, some investors have submitted their proposals to the regional investment bureau to engage in the livestock sector and crop productions along the river banks. The regional diaspora is also returning back with adopted technologies to make investments into their own lands (Ministry of Agriculture, 2002). However, after obtaining a license, the vast majority of private investors didn't start their investment projects. Here, the lesson is that awaiting the private sector's investment in the remote areas is unrealistic. The concerned regional states have to cover the investment gaps through establishing their own enterprises. The legal basis is as follows.

The FDRE Constitution incorporated economic and social rights and the correlative duty of the government (FDRE Constitution, 1995, Art 41). By virtue of Art 41(6), for instance, the state is obliged to pursue policies that enable to create job opportunities for the unemployed and the poor and to undertake public work projects. Likewise, the preamble of public enterprise proclamation provides that "the government of Ethiopia has adopted a new economic policy and it has become necessary to take successive measures for the implementation of this policy" (Proclamation No. 25/1992, Preamble). Moreover, by virtue of Art 89 (4) of the Constitution, the government is constitutionally obligated to provide special assistance to economically and socially least advantaged groups. It specifically says the "Government shall provide special assistance to Nations, Nationalities, and Peoples least advantaged in economic and social development."

Like the federal government, regional states also have exclusive authority over economic matters reserved to them, and they can carry out their economic mandates through the creation of public enterprises of their own. The states can, particularly, enact laws for the establishment of public enterprises. In this regard, the FDRE Constitution provides that states have a power "to formulate and execute economic, social and development policies, strategies and plans of the State" (FDRE Constitution, art. 52 (2) (c)).

The public enterprise proclamation has stipulated the organization and governance of a public enterprise in Art 10. According to this provision, each enterprise shall have supervising authority, management board, general manager, and employees. Dagnachew \& Addissie assert that "The supervising authority appears in Art 10(1) as if it were part of the organizational set-up of the enterprise. But it is an organ belonging to the executive government bestowed with the protection of the ownership rights of the state over a public enterprise than 
an organ operating within the enterprise itself for the enterprise; it is a controlling organ that plays a role of limiting extreme autonomy of the enterprise" (Dagnachew Asrat \& Addissie Shiferaw, 2009: p. 82). There is a comparable governance structure to the above one in other countries. In countries like India, which have a two-tier structure of governance, an enterprise works through right channels and continuous dialogue between the executives and non-executives, i.e. the supervisory organ and board management; and political interference is very limited (Richard, 2010: p. 8). Under the public enterprise law of Ethiopia, the supervising authority is controlled by individuals come from the executive organ of the state-the government puts its own personnel. Even if it is desirable to appoint key personnel by the criteria of professional skill, experience, and competence (Proclamation No 25/1992, Art 12 (4)), the practical situation in Ethiopia shows the contrary. These selection criteria are also, all most in a similar fashion, enshrined under OECD principles of corporate governance of state-owned enterprises. Principle VII (C) says "SOE board composition should allow the exercise of objective and independent judgment. All board members, including any public officials, should be nominated based on qualifications and have equivalent legal responsibilities" (OECD, 2015, Principle VII (C)).

In the Ethiopian context, OECD criteria serve the purpose of mitigating election or appointment based on mere political affiliation. It is important to urge consistency of state policy with the need to run enterprises efficiently and professionally. Here, ideally, it can be said that such efficiency approach of the law goes with the disciplinary theories of corporate governance which come under the perspective of efficiency (Aguilera \& Jackson, 2003: pp. 447-465).

In Ethiopia, it seems that management boards of SOEs have been elected based on their political obedience rather than their competence. The management board is not autonomous with regard to the formulation of broader policy issues. It has only a partial decision-making power, that is, either it only recommends such decisions or its sphere of action is very minimal. It seems that governmental control is justified here. This approach of the law is contrary to the OECD principle that deals with the need for limiting government interference: "Mechanisms should be implemented to avoid conflicts of interest preventing board members from objectively carrying out their board duties and to limit political interference in board processes" (OECD, 2015, Principle VII (E)). The boards of state-owned enterprises should be composed in a manner that is enabling to exercise objective and independent judgment (OCED, 2015).

\subsection{Investment through Endowment Companies}

The Charities and Societies Proclamation (CSP) No. 621/2009 which guides the registration and operation of charities and societies was put in place "to aid and facilitate the role of Charities and Societies in the overall development of Ethiopian peoples" and "... to ensure the realization of citizens' right to association enshrined in the Constitution" (Proclamation No. 621/2009, preamble). Since 2009 eight directives were issued to operationalize the proclamation. These in- 
clude consortium directive, 70/30 directive, charitable committee directive, endowment directive, local fundraising directive, charities property guideline, income generating activities directive, and audit report directive.

Generally, the primary laws governing charitable endowments are the above frameworks. As provided under CSP, a charitable endowment is an organization by which certain property is perpetually and irrevocably destined by donation or will or the order of the Agency for a purpose that is solely charitable (Article 16). In literal understanding, a charitable endowment is established for the purpose of humanitarian assistance. Coming to its investment companies, they are designed for the purpose of profit making rather than engaging for direct humanitarian activities. This has a legal base, that is, the endowment may engage in income generating activities which are incidental to the achievement of its purpose (Proclamation No. 621/2009, Art 103). Accordingly, party-affiliated charitable endowments, like EFFORT, have created two wings: charity and investment. The activity of the charity wing is governed by the above-mentioned charity and society organizations (CSOs) legal framework, whereas the investment wing (companies) governed by the commercial laws of Ethiopia.

The issue of governance: In principle, the law recognizes the rights of CSOs to determine their own structure (Proclamation No. 621/2009, Art 58). Nevertheless, there are some provisions that require CSOs to adopt certain forms of structure. Charitable endowments must have a board of management, manager, and auditor within their structure of governance (Proclamation No. 621/2009, Art 19). The law has also mandated supervisory organs to oversee the administration and operation of CSOs (Proclamation No. 621/2009, Art 6).

The governance aspect of the endowment companies follows a different system compared to SOEs. Like other private companies, they are established by taking one of the forms of a business organization governed by the commercial code of Ethiopia. Their governance affairs are also determined by the commercial code based on the form they take (Commercial Code, Art 212).

Utilization of fund: the utilization of fund of charitable endowments is governed by CSP and the 70/30 directive (the directive issued to determine the operational versus the administrative costs of Charities \& Societies). Article 90 of the CSP deals with the regulation of administrative and operational costs. It reads "any charity or society [organization] shall allocate not less than 70 percent of the expenses in the budget year for the implementation of its purposes and an amount not exceeding 30 percent for its administrative activities" (Proclamation No. 621/2009, Art 90). Regarding endowment companies, there is no legal restriction concerning the way of utilizing their income. That means that they can use their income to expand their investments and/or spend on charitable activities.

Moreover, there is an income tax exemption for charities. This is an affirmative approach which enhances their financial capacity. However, endowment companies are not exempted from any tax-they are required to pay tax as other private companies. 
In Ethiopia, there are serious concerns over party-affiliated endowments. They have taken many of the business opportunities of the country displeasing private companies. Another area of criticism is that these endowment companies operate their businesses in non-pastoral areas of the country. This means that they are contributing to the historically-rooted income inequality created between the pastoral and non-pastoral communities of Ethiopia. It is not always clear to what extent political considerations reflect the business strategies of those firms, and vice versa (Ethiopian Economic Association, 2005). High ranking party members manage endowment-owned firms. At another level, a write-off the debt owed by party-affiliated enterprises to state-owned banks would constitute a transfer of wealth from the state to the endowments (Ethiopian Economic Association, 2005).

Endowment-owned firms are not uniformly profitable. Many of the firms appear to suffer from inefficiencies typically associated with state-owned enterprises, including non-commercial objectives that weaken commercial sustainability. It is widely understood that a significant share of the non-performing loan portfolio of state-owned banks represents what were originally loans to endowment-owned firms (Taffesse, M., 2008). So, what should be promoted is a non-political party-affiliated endowment company which may be established by any interested person from the public. There should be a strict regulation to make sure that the ultimate aim of establishing such types of companies is, for the purpose of this article, benefiting the disadvantaged pastoral areas of the country.

\section{The Complementary Role of State-Owned Enterprises and Endowment Companies}

The government, in order to put into practice the constitutional duty, can establish enterprises of its own to avoid confinement in relatively developed metropolitan areas and to expand and market their economic and social activities in rural pastoral territories irrespective of incurring losses. The enterprises are able to offset losses from the huge profit they earn from their activities in developed areas or even they may obtain a subsidy from the government for such. In relation to this, endowment companies have also a comparable role. They can open up new projects into which the private sector business may follow once infrastructure and a precedent have been established (Sarah Vaughan \& Mesfin Gebremichael, 2011). This means that the companies, like that of public enterprises, engage without calculating their profits rather it is for the sack of socio-economic benefits of the pastoral areas. Consistently with the social dimension implicit in their nature, public enterprises and endowment companies can play a key role in providing access to public health and education, clean water, housing, food, and social security. Or else can apportion resources from their profitable public enterprises in the form of profit share or dividends to directly allocate same for specifically benefiting the least advantaged segment of the pastoral community (Sarah Vaughan \& Mesfin Gebremichael, 2011). 
Endowment companies may have similar economic features as a public enterprise. This is to utilize them as an instrument "to promote the industrialization of their respective regions and to contribute to the development of human resources in the respective regions, especially to the establishment of research and training institutions" (Sarah Vaughan \& Mesfin Gebremichael, 2011). The charitable endowments and the government do not merely intend to establish endowment companies and public enterprises respectively but also geared them in so far as it is appropriate to discharge the various economic and social responsibilities mandated by the Constitution to the government.

In sum, public enterprises and endowment companies have a complementary role, that is, their ultimate goal is to benefit the socio-economic development of the nation but not to enjoy profits for certain individuals unlike private companies. Pastoral regional states should consider the role of SOEs and endowment companies in generating income options to the pastoral communities, especially through creating job opportunities.

\section{Adopting a Suitable Political Economy Model}

The author of this article is of the opinion that Ethiopia has to follow a political economy model that suites to a nation with a low-income economy and poor democratic practice as well as communal, religious, and multi-ethnic society. Accordingly, I suggest such a model should enable to:

1) Mitigate income inequality and provide social welfare;

2) Create an opportunity for economic interventionism/state interventionism to regulate the market both at macro and micro levels;

3) Allow the government to engage in some selected commercial activities only with a view to generating income to cover the costs of social welfares, instead of imposing a heavy tax on the private sectors;

4) Allow the establishment of state-owned enterprises and endowment companies so as to cover the economic gap that may be created due to the inability or unwillingness of the private sector to invest in every part of the country; and

5) Realize political, economic and religious freedoms in their real sense.

Given the nature of Ethiopian State, a single model cannot sufficiently address the existing diversified interests, i.e. those interests mentioned herein above. Hence, following a mixed model will be an uncontested approach to sufficiently address the democratic and economic demands without making one to the cost of another. The elements of one model may not be compatible with the demand of highly-diversified ethnic societies having different economic, political, religious, and cultural interests. However, if a mixed model adopted, the negative side of one model can be replaced by the positive element of another model. So, following a mixed model is very important for this and other similar justifications.

The choice of the political economy model needs to be from those having a relatively close relationship and able to directly or indirectly address different interests when mixed together. In line with this, Social Democracy and Deve- 
lopmental State can be taken as best examples that can be mixed together to address Ethiopia's democratic and economic demands respectively.

When compared with Liberal and Conservative ideologies, the elements of social democracy are suitable for the type of democracy and society Ethiopia need to create. Greater equality, stronger bonds of community, etc., are all things which social democrats see as important changes (Kastning, 2013). But, for liberals and conservative, individual freedom has absolute priority over equality and solidarity, and the individual over society (Takis Fotopoulos, 2006). Social democrats have a conception of freedom that accepts liberal and even some conservative notions, but also includes the notion that people are not free if they do not have the resources to do certain things (Kastning, 2013). Social democrats assert that political freedom is also mean economic freedom. Unlike the liberal and conservative, Social democracy advocates that social welfare is a fundamental part of society, and as the democratic expression of society (Julia, 2009). Regarding the role of the state in the economy, social democracy allows greater state intervention than liberal and conservative ideologies. Overall, liberal and conservative ideologies best suited for an advanced economy, and civilized and individualistic society. Whereas social democracy best suited for a country with low economic status, poor social provisions, and divers and communal type of society (Julia, 2009).

Regarding developmental state, the very justification for picking this model is looking at its approach towards the role of the state in the economy. This model allows the government to establish state-owned enterprises with a view to creating jobs and generating income for the support of the state budget needed for the provision of social services (UNCTAD, 2013). The government can also invest in the areas where the private sector could not cover. But, this model could not be an option to realize democracy as its approach does not incorporate democratic elements either in the theoretical or actual declaration. This model is compatible only with our economic demands. Hence, our democratic demands best addressed by taking the elements of social democracy.

Therefore, from the perspective of the interest of pastoral areas, the above justifications lead us to conclude a mixed political economy model that integrates social democracy and developmental state is crucial to best address the different socio-economic demands of the pastoral community. This can be done through investments operate by state-owned enterprises and endowment companies in one hand and through social welfare on the other hand.

\section{Conclusion}

The FDRE Constitution provides that pastoralists should be benefited from the development of the country equally with other people residing in different parts of the country. To this end, the government has tried to improve the livestock production sector. Most of the previous poverty reduction policy and legal frameworks stick to the improvement of livestock production. But, other income generating means are not given the required level of attention as much as the 
non-pastoral areas.

The income option that might be created through the investments of state-owned enterprises and endowment companies should not be underestimated. The Constitution allows economic intervention by the state in pastoral areas than any other parts of the country. This is due to the fact that the pastoral areas are the most disadvantaged parts of Ethiopia that require special attention which can be exhibited through enacting workable legal and policy frameworks compatible to the socio-economic realms of the pastoral community. This can be achieved through promoting investment and industrialization opening up state-owned enterprises and endowment companies in the pastoral areas. However, to sustain and strengthen investment through these business entities, it is important to draw the relevant lessons from the existing enterprises and endowment companies operating in non-pastoral areas of Ethiopia.

State-owned enterprises should entirely be led by professionals recruited not because of their political affiliation, but based on their competence. Concerning endowment companies, the suggestion is that rather than establishing political party-affiliated endowments, it is desirable to encourage public-led endowments which may take the forms of business organizations contained in the commercial code.

It is understandable that to sustain and strengthen state-owned enterprise and, to some extent, endowment companies, the type of political economy model matters. The author is of the view that Ethiopia should follow a mixed political economy model to effectively address the various democratic and economic interests of the country. In this regard, social democracy and developmental state models can be integrated to allow the necessary economic intervention by the government, provide social welfare, and mitigate income inequality as well as to build democracy in its real sense. Liberal and conservative models are rejected on theoretical and compatibility grounds, however.

\section{Acknowledgements}

I would like to thank my beloved wife Woinshet Mohamed, Selman Seid and Rumeysa (Mar ena Work) Seid for their technical assistance in this research work.

\section{Conflicts of Interest}

The author declares no conflicts of interest regarding the publication of this paper.

\section{References}

Aguilera, R., \& Jackson, G. (2003). The Cross-National Diversity of Corporate Governance: Dimensions and Determinants. Academy of Management Review, 28, 447-465. https://web.northeastern.edu/ruthaguilera/wp-content/uploads/2017/02/3.-Aguilera-Ja ckson-2003-AMR.pdf https://doi.org/10.5465/amr.2003.10196772

Admassie, A., \& Abebaw, D. (2014). Rural Poverty and Marginalization in Ethiopia: A 
Review of Development Interventions.

https://www.researchgate.net/publication/274386917_Rural_Poverty_and_Marginalizat ion_in_Ethiopia_A_Review_of_Development_Interventions

Asrat, D., \& Shiferaw, A. (2009). Law of Public Enterprises and Cooperatives. Teaching Material, Justice and Legal System Research Institute of Ethiopia.

https://chilot.me/wp-content/uploads/2011/06/public-enterprises-and-cooperatives.pdf

Ethiopian Economic Association (2005). Industrialization and Industrial Policy in Ethiopia. Research Report, Addis Ababa.

Ethiopian Investment Commission (2012). Investment Incentives (p. 4).

Elias, E., \& Abdi, F. (2010). Putting Pastoralists on the Policy Agenda: Land Alienation in Southern Ethiopia (p. 3).

FDRE Constitution (1995). Federal Negarit Gazeta, Extraordinary Issue, Proc. No. 1, 1st Year, No. 1. http://www.wipo.int/edocs/lexdocs/laws/en/et/et007en.pdf

FDRE (2010). Growth and Transformation Plan 2010/11-2014/15 (pp. 25-27). Ministry of Finance and Economic Development.

http://www.ethiopians.com/Ethiopia_GTP_2015.pdf

FDRE (2015). The Growth and Transformation Plan II (2015/16-2019/20) (p. 31). National Planning Commission.

http://dagethiopia.org/new/docstation/com_content.article/100/gtp_ii_policy_matrix_e nglish_final__august_2016.pdf

Future Agricultures (2011). Innovation Works: Pastoralists Building Secure Livelihoods in the Horn of Africa. Policy Brief. http://www.future-agricultures.org

Gadamu, F. (1994). The Post-Revolutionary Rethinking of Arid Land Policy in Ethiopia. Nomadic Peoples, 7-21.

http://www.jstor.org/stable/43124073?seq=1\#page_scan_tab_contents

Hogg, R. (1997). Pastoralists, Ethnicity and the State in Ethiopia (p. 23). Haan Publishing.

Holly Welcome Radice, et al. (2011). Technical Brief: Participatory Natural Resource Management with Somali Pastoral \& Agro-Pastoral Communities in Ethiopia: A Lasting Community-Led Response to Climate Change (p. 1). Save the Children UK. https://www.preventionweb.net/files/21319_technicalbriefparticipatorynrmscuke.pdf

Bläsius, J., et al. (2009). Foundations of Social Democracy (p. 89). Friedrich-Ebert-Stiftung Publishing. http://library.fes.de/pdf-files/iez/07077.pdf

Ministry of Agriculture (2002). Historical Accounts of Livestock, Fishery and Animal Health from 1992 to 1993 EC. Addis Ababa.

MoFED (2002). Sustainable Development and Poverty Reduction Program of Ethiopia. Addis Ababa.

http://siteresources.worldbank.org/INTETHIOPIA/Overview/20207639/2002_07_prsp. pdf

MoFED (2006). Plan for Accelerated and Sustained Development to End Poverty, 2005/06-2009/10 Plan. Addis Ababa.

https://www.afdb.org/fileadmin/uploads/afdb/Documents/Policy-Documents/Plan_for _Accelerated_and_Sustained_(PASDEP)_final_July_2007_Volume_I_3.pdf

Mohammed, N. A. (2006). The Role of Microfinance in Strengthening Pastoral Household Food Security a Comparative Study between Beneficiaries and Non-Beneficiaries of Microfinance Services in Dollo Ado and Filtu Districts of Somali Region (p. 71).

Pastoral Development in Ethiopia (2004). Pastoralist Forum Ethiopia (p. 34).

Proclamation No. 25/1992 (1992). Public Enterprise Proclamation. Addis Ababa: Berhanena Selam Printing Enterprise. 
https://chilot.me/2011/02/public-enterprises-law-proclamation-no-251992/

Proclamation No. 621/2009 (2009). Charities and Societies Proclamation. Addis Ababa: Berhanena Selam Printing Enterprise.

https://chilot.me/wp-content/uploads/2011/02/charities20and20societies20proclamatio $\underline{\text { n.pdf }}$

Rekhy, R. (2010). Corporate Governance in the Public Sector-The Road Ahead (p. 8).

OECD (2015). Guidelines on Corporate Governance of State-Owned Enterprises. Paris: OECD Publishing. https://doi.org/10.1787/9789264244160-en https://eclass.uoa.gr/modules/document/file.php/LAW307/OECD\%20GUIDELINES\% 202015\%20SoE.pdf

Pantuliano, S., \& Wekesa, M. (2008). Improving Drought Response in Pastoral Areas of Ethiopia. CARE, FAO, Save the Children UK and Save the Children US.

https://www.odi.org/sites/odi.org.uk/files/odi-assets/publications-opinion-files/2043.pd $\underline{\mathrm{f}}$

Vaughan, S., \& Gebremichael, M. (2011). Rethinking Business and Politics in Ethiopia-The Role of Effort (pp. 35-57). Research Report.

Taffesse, M. (2008). The Ethiopian Civil Service Reform Program. In T. Assefa (Ed.), Digest of Ethiopia's National Policies, Strategies, and Programs (pp. 373-417). Addis Ababa: Forum for Social Studies.

Fotopoulos, T. (2006). Liberal and Socialist “Democracies” versus Inclusive Democracy. The International Journal of Inclusive Democracy, 2, 4-5.

http://www.inclusivedemocracy.org/journal/pdf\%20files/pdf\%20vol2/Liberal\%20and\% 20Socialist\%20Democracies\%20verdus\%20ID.pdf

Kastning, T. (2013). Basics on Social Democracy (pp. 34-36). Friedrich-Ebert-Stiftung Publishing.

http://www.fesghana.org/uploads/PDF/Brochure_SocialDemocracy_FINAL.pdf

UNCTAD (2013). The Asian Developmental State and the Flying Geese Paradigm (pp. 3-4). Discussion Paper. http://unctad.org/en/PublicationsLibrary/osgdp20133_en.pdf

Zeller, M., et al. (1997). Rural Finance for Food Security for the Poor: Implications for Research and Policy (p. 29). Washington DC: IFPRI. 